\title{
Cannabinoids and the immune system
}

\author{
Thomas W Klein PhD*, Catherine A Newton, Herman Friedman PhD
}

\section{TW Klein, CA Newton, H Friedman. Cannabinoids and the immune system. Pain Res Manage 2001;6(2):95-101.}

The effect of cannabimimetic agents on the function of immune cells such as $\mathrm{T}$ and $\mathrm{B}$ lymphocytes, natural killer cells and macrophages has been extensively studied over the past several decades using human and animal paradigms involving whole animal models as well as tissue culture systems. From this work, it can be concluded that these drugs have subtle yet complex effects on immune cell function and that some of the drug activity is mediated by cannabinoid receptors expressed on the various immune cell subtypes. However, the overall role of the cannabinoid system of receptors and ligands in human health and disease is still unclear and requires extensive elucidation. Further studies will define the precise structure and function of the putative immunocannabinoid system, the potential therapeutic usefulness of these drugs in chronic diseases such as acquired immune deficiency syndrome and multiple sclerosis, the effects of these agents on tumour growth and induction of apoptosis, and the potential anti-inflammatory and proinflammatory properties of cannabimimetic compounds. It is likely that the cannabinoid system, along with other neuroimmune systems, has a subtle but significant role in the regulation of immunity and that this role can eventually be exploited in the management of human disease.

\section{Cannabinoïdes et système immunitaire}

RÉSUMÉ : L'effet des agents cannabimimétiques sur le fonctionnement des cellules immunitaires comme les lymphocytes $\mathrm{T}$ et $\mathrm{B}$, les cellules $\mathrm{K}$ et les macrophages a fait l'objet de nombreuses études au cours des dernières décennies à l'aide de paradigmes humains et animaux faisant appel à des modèles animaux entiers ainsi qu'à des systèmes de culture de tissus. Il ressort de toutes ces études que les médicaments cannabimimétiques produisent des effets discrets mais complexes sur le fonctionnement des cellules immunitaires et que l'activité médicamenteuse est médiée en partie par des récepteurs cannabinoïdes qui s'expriment sur les divers sous-types de cellules immunitaires. Toutefois, le rôle global du système cannabinoïde de récepteurs et de ligands dans la santé et les maladies humaines reste obscur et demande à être élucidé. Ainsi, des études porteront sur la structure et le fonctionnement précis du système immuno-cannabinoïde présumé, sur le rôle thérapeutique éventuel de ces médicaments dans des maladies chroniques comme le syndrome d'immunodéficience acquis et la sclérose en plaques, sur l'effet de ces substances sur la croissance des tumeurs et l'induction de l'apoptose ainsi que sur les propriétés anti-inflammatoires et pro-inflammatoires possibles des composés cannabimimétiques. Il semble bien que le système cannabinoïde, tout comme d'autres systèmes neuroimmunitaires, joue un rôle discret mais significatif dans la régulation de l'immunité et que ses propriétés pourront un jour être exploitées pour le traitement des maladies humaines.

Key Words: Cannabinoid; Cannabinoid receptor; Immunity; Lymphocyte; Marijuana; Tetrahydrocannabinol

University of South Florida, College of Medicine, Tampa, Florida, USA

Correspondence and reprints: Thomas W Klein, University of South Florida, College of Medicine, Department of Medical Microbiology and Immunology, MDC Box 10, 12901 Bruce Downs Boulevard, Tampa, Florida 33612, USA. Telephone 813-974-2502, fax 813-974-4151, e-mail tklein@hsc.usf.edu

*Dr Klein is Professor and Vice Chair of Medical Microbiology and Immunology at the University of Southern Florida. He is considered one of the world's best authorities in the area of cannabinoids and immunity. Dr Klein's work focuses on the role of cannabinoids in immune regulation. Dr Klein has served as consultant on cannabinoids to the World Health Organization, the Institute of Medicine of the National Academy of Sciences and the Wellcome Trust England. He has made major contributions to the world literature regarding cannabinoid effects on the immune system. Dr Klein wrote the chapter on cannabis and immunity in the comprehensive text The Health Effects

of Cannabis, and he contributed the section on Cannabinoids and the Immune System in the Institute of Medicine's publication,

Marijuana and Medicine; in short, where there is a state-of-the-art review on this topic, Dr Klein has been sought as the first author. 
$\mathrm{F}$ or years, the debate has raged concerning the potential use of marijuana as medicine. In 1997, the United States government asked the Institute of Medicine of the United States National Academy of Sciences to assess this issue. The Institute of Medicine (IOM) issued its report in 1999 (1), which concluded that much had been learned about cannabinoid biology and the so-called cannabinoid system of mammals. These data, in total, suggested that cannabinoids do have the potential to be therapeutic agents and that clinical trials and symptom management assessment should be undertaken. In addition to the IOM report, political change in both the United States and Canada has favoured, over the past few years, the medical use of marijuana. Because of all of these events, marijuana and cannabinoid use will likely increase in the United States and Canada both in the general population and as a therapeutic agent in the treatment of chronic diseases such as multiple sclerosis and chronic pain, and as an appetite stimulant following chemotherapy or acquired immune deficiency syndrome (AIDS) wasting syndrome. Although much has been learned concerning the chemistry and biology of marijuana and cannabinoids (1), the IOM report concluded that much more needed to be learned in all areas of cannabinoid biology, including effects on the immune system. In the present report, we summarize some of the evidence concerning the effects of cannabinoids on immune function and also summarize what is known concerning the immunobiology of the cannabinoid system. Several reviews of this subject have appeared recently (2-7). Furthermore, we present some key issues that should be addressed for a better understanding of the impact of cannabinoid therapy on immune function, and of the overall effect of marijuana and its derivatives on human health and disease.

\section{CANNABINOID EFFECTS ON IMMUNE FUNCTION}

The immune system is a complex network of cells, tissues and soluble mediators, including cytokines and hormones (Figure 1). Initial maturation of stem cells to competent lymphocytes occurs in primary lymphoid organs such as thymus and bone marrow. This maturation is extremely important in that it promotes the development of immune cells that recognize nonself antigens, allowing the immune system to recognize foreign antigens rather than self antigens, thus suppressing the tendency toward autoimmunity. Maturation in these organs is regulated by hormones such as corticosteroids and cytokines such as colony-stimulating factors, and is susceptible to modulation by drugs such as cannabinoids. Mature lymphocytes exit the thymus and bone marrow, and migrate to secondary lymphoid organs such as the spleen, lymph node, etc (Figure 1). Here, they comingle with other cellular elements of immunity, such as macrophages, dendritic cells, neutrophils, etc, and together produce the immune response when antigens and microbes enter these organs. These cellular interactions, as in the thymus and bone marrow, are also highly regulated by hormones and cytokines and, in addition, are susceptible to influences by drugs such as cannabinoids. Antigen stimula-

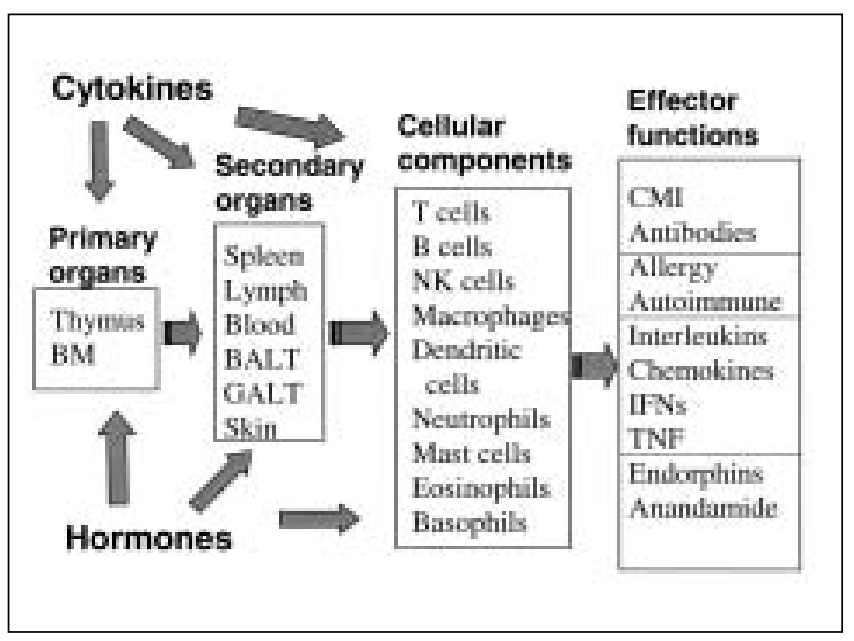

Figure 1) The immune system. Stem cells mature to competent lymphocytes in primary lymphoid organs such as thymus and bone marrow (BM). The mature lymphocytes migrate to secondary lymphoid organs such as the spleen, lymph node, blood, bronchial lymphatic tissue (BALT), gut-associated lymphatic tissue (GALT) and skin, where they interact with the other main cellular components of the immune system. Foreign antigen induces these cells to produce the various effector functions of immunity, including cellmediated immunity (CMI) and antibodies, allergy and autoimmunity, chemokines and cytokines such as interferons (IFNs) and tumour necrosis factor (TNF), and neuroimmune hormones such as endorphins and anandamide. NK Natural killer

tion results in the generation of the various immune effector functions, such as cell-mediated immunity, antibody production, manifestations of allergy and autoimmunity, interleukin and cytokine production, and the production of a variety of biologically active substances such as endorphins and cannabimimetics such as anandamide (Figure 1). These and other immune manifestations form the basis for resistance to infections and tumours, and affect other physiological processes in the body ranging from general hematopoiesis to psychological mood. Clearly, this complexity of the immune system provides a variety of entry points at which cannabinoids and other drugs may interact with and alter normal immune homeostasis, making analysis of drug effects on immunity a long and difficult process.

\section{Human and animal studies}

Drug effects on immune function can be examined using a variety of experimental paradigms. One of these involves the removal of immune cells from humans and animals exposed to marijuana, and examining whether cellular immune functions have been altered. Some of the earliest work examining the effect of marijuana on immunity dates back to the early 1970 s and involves this kind of study. Peripheral blood leukocytes were removed from marijuana smokers, and changes in $\mathrm{T}$ cell proliferation were studied (Table 1). The results were mixed, depending on the report, with at least one group showing a decrease in proliferation (8) and another group showing no effect (9). Other T cell functions were also studied (Table 1) with mixed results, suggesting that significant depression of peripheral blood 
TABLE 1

Cannabinoid effects on immunity in humans and animals

\begin{tabular}{|c|c|c|c|}
\hline Model & Cell type & Function & Effect \\
\hline \multirow[t]{8}{*}{ Human } & T cells & - Proliferation & $\downarrow$ or none \\
\hline & & - Rosette formation & $\downarrow$ \\
\hline & & - CD4:CD8 ratio & $\uparrow$ \\
\hline & B cells & - Immunoglobulin E & $\uparrow$ \\
\hline & & - Immunoglobulin G & $\downarrow$ \\
\hline & Macrophages & - Phagocytosis & None \\
\hline & & $\begin{array}{l}\text { - Antimicrobial activity and } \\
\text { cytokine production }\end{array}$ & $\downarrow$ \\
\hline & NK cells & - Cytolysis & None \\
\hline \multirow[t]{8}{*}{ Animal } & T cells & - Cytolysis & $\downarrow$ \\
\hline & & - Antimicrobial activity & $\downarrow$ \\
\hline & & - Antitumour activity & $\downarrow$ \\
\hline & B cells & - Antibody production & $\downarrow$ \\
\hline & Macrophages & - Protein production & $\downarrow$ \\
\hline & & - IL-1, IL-6, TNF- $\alpha$ production & $\uparrow$ \\
\hline & & - Cytolysis & $\downarrow$ \\
\hline & NK cells & - Cytolysis & $\downarrow$ \\
\hline
\end{tabular}

$\overline{\downarrow \text { Decrease; } \uparrow \text { Increase; IL Interleukin; NK Natural killer; Th T helper; }}$ TNF Tumour necrosis factor

leukocyte $\mathrm{T}$ cell function cannot be readily demonstrated in the cells of marijuana smokers. Equivocal results were also obtained in studies examining other immune cell subpopulations removed from marijuana smokers (Table 1), with either no effects or limited effects associated with marijuana use. However, harmful effects of drug use cannot be ruled out. Recently, at least one report has shown significant functional changes in alveolar macrophages taken from the lungs of marijuana smokers, suggesting that certain immune cell populations are affected by drug use in terms of the ingestion and killing of bacteria and the production of cytokines such as tumour necrosis factor-alpha (TNF $\alpha)$, granulocyte-macrophage colony-stimulating factor and interleukin (IL)-6 (10).

Experimental animals exposed to marijuana and cannabinoids have also been studied (Table 1). For example, monkeys exposed to marijuana smoke displayed lower $\mathrm{T}$ cell mitogen responses and serum antibody (11). In addition, mice exposed to cannabinoids showed reduced antibody production (12,13), natural killer (NK) cell activity (14) and macrophage function (15). Recently, defects in T cell function in mice following THC injection have been shown to be associated with reduced host resistance to infection and tumours (Table 1). For example, mice were injected with tetrahydrocannabinol (THC), followed a day later by infection with a bacterial pathogen (16). It was observed that THC, under these conditions, inhibited the development of immunity to the bacterial challenge through mechanisms involving the suppression of $\mathrm{T}$ helper cells. Similar findings were observed in a tumour immunity model (17). Here, repeated injections of THC into mice inhibited the development of
TABLE 2

Cannabinoid effects on immunity in human and animal cell cultures

\begin{tabular}{|c|c|c|c|}
\hline Model & Cell type & Function & Effect \\
\hline \multirow[t]{5}{*}{ Human } & T cells & - Proliferation & $\downarrow$ \\
\hline & B cells & - Proliferation & $\uparrow$ \\
\hline & Macrophages & - Nitric oxide release & $\uparrow$ \\
\hline & & - Tumour necrosis factor-alpha & $\downarrow$ \\
\hline & NK cells & - Cytolysis & $\downarrow$ \\
\hline \multirow[t]{18}{*}{ Animal } & T cells & - Proliferation & $\downarrow$ \\
\hline & & - Cytolysis & $\downarrow$ \\
\hline & & - Th1 cell activity & $\downarrow$ \\
\hline & & - Th2 cell activity & $\uparrow$ \\
\hline & & - Interleukin-2 & $\uparrow$ or $\downarrow$ \\
\hline & & • NF-AT & $\downarrow$ \\
\hline & & - NF-кB & $\uparrow$ \\
\hline & B cells & - Antibody production & $\downarrow$ \\
\hline & & - Proliferation & $\downarrow$ \\
\hline & Macrophages & - Phagocytosis & $\downarrow$ \\
\hline & & - Antigen processing & $\downarrow$ \\
\hline & & - $\mathrm{AA}$ and ANA production & $\uparrow$ \\
\hline & & - Interleukin-1 & $\uparrow$ \\
\hline & & - Tumour necrosis factor-alpha & $\downarrow$ \\
\hline & & - Nitric oxide release & $\downarrow$ \\
\hline & NK cells & - LAK-cell activity & $\downarrow$ \\
\hline & & - Interleukin-2 receptor & $\uparrow$ or $\downarrow$ \\
\hline & & - Cytolysis & $\downarrow$ \\
\hline
\end{tabular}

$\downarrow$ Decrease; $\uparrow$ Increase; AA Arachidonic acid; ANA Anandamide; LAK Lymphokine-activated killer; NK Natural killer; NF-AT Nuclear factor

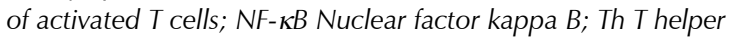

immunity to a tumour cell challenge by mechanisms involving an imbalance in $\mathrm{T}$ cell cytokine production. Of interest, both of these studies showed an involvement of cannabinoid receptors in mediating the immune suppressive effects. From the above studies, it appears that exposure of humans and animals to marijuana and its components affects a variety of immune functions, with the predominating effect being one of suppression. Furthermore, high drug doses probably affect immunity by mechanisms that bypass cannabinoid receptor involvement. However, lower doses appear to affect $\mathrm{T}$ cell function through receptor-mediated mechanisms.

\section{Cell culture studies}

Drug effects on immune function can also be determined by removing immune cells from nondrug-treated humans and animals, and then treating these cells in culture with the various drug preparations (Table 2). In these types of studies, the functions of human T cells (18) and NK cells (19) were found to be suppressed by THC and other cannabinoids, which were similar to drug-induced suppression observed in vivo (see above). Interestingly, however, human B cells from tonsils cultured with various cannabimimetics were observed to display increased proliferation in response to drug treatment 


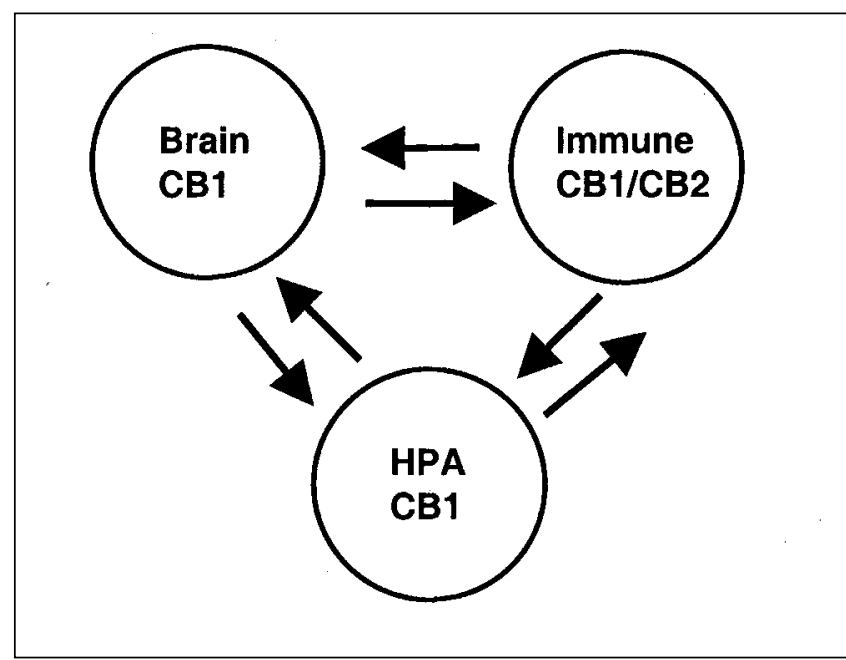

Figure 2) Cannabinoid system interactions. The brain, immune system and hypothalamic-pituitary-adrenal (HPA) axis have all been shown to express cannabinoid receptors and anandamide. The immune system appears to express both receptor subtypes. The cannabinoid system possibly supports bidirectional communication between neural and immune tissues along with other neuroimmune hormones and cytokines

(20). Furthermore, the drug effect appeared to be mediated by a cannabinoid receptor-dependent mechanism. Macrophages isolated from human peripheral blood preparations have also been shown to be responsive to cannabimimetics. For example, stimulation of TNF- $\alpha$ production by endotoxin was suppressed by THC treatment (21), whereas production of nitric oxide by cultured macrophages was increased by the endocannabimimetic anandamide, by mechanisms involving cannabinoid receptors (22)

Many studies involving animal immune cell cultures have been performed, and as with human cells, cannabinoid treatment led to either an increase or a decrease in cellular function (Table 2). For example, murine $\mathrm{T}$ and $\mathrm{B}$ cell proliferation was suppressed by drug treatment $(23,24)$ as was $\mathrm{T}$ cell and NK cell killing $(25,26)$, and B cell antibody production $(27)$. The production of cytokines by immune cells was also affected by cannabinoids. The production of various types of interferons was shown to be decreased after THC treatment of cultured murine cells, as was IL-2, TNF- $\alpha$ and others $(5,28)$. However, cytokines such as IL- 1 and TNF- $\alpha$ were also shown to be increased by drug treatment $(5,28)$, underscoring the complexity that cannabinoid treatment has on proinflammatory and anti-inflammatory mechanisms. Because these cytokine changes are related to changes in signalling cascades, several reports have implicated alterations in the transcription factors nuclear factor of activated $\mathrm{T}$ cells and nuclear factor kappa B in the drug effects on IL-2 (29) and IL-2 receptor proteins (30). Undoubtedly, similar types of studies will help to determine the mechanisms of cannabinoid effects on gene expression in immune cells.

Other complex immune mechanisms are reported to be altered after drug treatment in vitro. For example, the processing of antigens by macrophages for presentation to $\mathrm{T}$ cells is altered by cannabinoid treatment (31). In summary, cannabinoid treatment alters a wide array of immune functions when added to cultures of human and animal cells. The role of cannabinoid receptors in many of these drug effects, as well as the relative significance of the in vitro findings to human health and disease, remain to be determined.

\section{IMMUNOCANNABINOID SYSTEM}

The brain and immune tissues appear to have a so-called cannabinoid system of specific receptors and ligands. This system, as well as others involving hormone and cytokine agents, serve to mediate communication between the various tissues (Figure 2) (32). Although much has been learned concerning the structure and function of the cannabinoid system, major gaps in understanding still exist, especially concerning the role of the cannabinoid system in immunity (ie, immunocannabinoid system). There are at least two subtypes of cannabinoid receptors (CBRs), termed $\mathrm{CB} 1$ and $\mathrm{CB} 2$. Initially, pharmacological evidence suggested the existence of these receptors in brain tissue (33), and the subsequent molecular cloning of the first subtype from a rat brain complementary DNA library (34) confirmed this conclusion. The second subtype, CB2, interestingly was cloned not from the the brain, but from a human immune cell line (35). Thus, it was apparent from the start that the CBR system existed not only in brain, as expected, but also in cells of the immune system. CBRs are classified within the seven transmembrane G protein-coupled receptor superfamily (36), and although they transduce signals through a pertussis toxin-sensitive $\mathrm{G}_{\mathrm{i}} / \mathrm{G}_{\mathrm{O}}$ inhibitory pathway, recent evidence suggests that they may couple to $G_{S}$ proteins as well (37). Interestingly, the $G$ protein pathways have been linked to signalling events in cells of the immune system (38). In addition to CBRs, the brain and peripheral tissues also contain endogenous ligands for these receptors (39). Chemically, these substances are based on arachidonic and palmitic acids rather then cannabinoids, and generally have a lower affinity for CBRs than cannabinoid derivatives (40). They are produced by cells in both the brain and immune systems (41), and their existence supports the current view of a complete cannabinoid system of endogenous receptors and ligands that regulates various physiological processes in both the brain and peripheral tissues (Figure 2).

The expression of CBRs outside of the brain was first indicated by the demonstration of CB1 mRNA expression in human testis tissue (42). This was followed by reports that murine splenocytes contained CB1 mRNA, as detected by reverse transcriptase polymerase chain reaction (43), and human peripheral blood mononuclear cells (PMBCs) also expressed the message (44). The second receptor subtype CB2 mRNA was also shown to be expressed in immune cells and rat spleen rather than brain (35), and was found to be expressed at higher levels than CB1 in these peripheral tissues (45). Not all cells of the immune system express CBRs equally. For example, the rank order of expression of $\mathrm{CB} 1$ in human PBMCs, in decreasing order, is B cells, NK cells, polymorphonuclear neutrophils, CD8 cells, monocytes and CD4 cells (44). This trend recently has also been observed in 
mouse splenocytes (46). For CB2, the rank order in human PBMCs, in decreasing order, is B cells, NK cells, monocytes, polymorphonuclear neutrophils and T cells (45), and again is similar in mouse cells (unpublished data).

These and other studies have helped to establish the current model for $\mathrm{CBR}$ distribution - that $\mathrm{CB} 1$ is primarily in the brain and associated structures, such as the pituitary (47) and peripheral nervous tissues (48), while CB2 is primarily in the reproductive and immune systems (Figure 2). These tissues express not only the various CBR subtypes but also the endogenous ligands, such as anandamide. Therefore, the cannabinoid system becomes yet another regulatory and communication system for the various organs in the body.

\section{KEY ISSUES FOR FUTURE STUDY}

Structure and function of the immunocannabinoid system Limited evidence shows that CBRs are expressed in selected immune tissues such as blood cells, the spleen and tonsils (see above). However, little is known concerning their expression in other immune tissues, such as the thymus, lymph node, bone marrow, gut and bronchial lymphatic tissues. This is a key issue because these tissues are of great importance in overall host resistance, and it cannot be assumed that the CBR expression is uniform throughout the entirety of immune tissues. Another key issue involves the regulation of CBR gene expression during the course of immune activation. Although several reports have suggested that both $\mathrm{CB} 1(46,49)$ and CB2 (50) receptors are increased after T cell and B cell activation, this phenomenon has not been observed under a diversity of activation conditions. Furthermore, little is known concerning the gene promoter region controlling CB1 and CB2 gene activation, as well as the transcription factors generated in immune cells that may control CBR gene activity. Signalling mechanisms linked to CBRs and the resulting gene activities in immune cells are other areas needing further investigation. Signalling through adenylyl cyclase in immune cells has been observed (51), as has activation of nuclear factor kappa B (30). However, other signalling cascades have been linked to CBRs in other tissues $(52,53)$ and, therefore, may also be active in immune cells. Besides CBR expression and function, another key issue involves the production by immune tissues of endogenous ligands for CBRs. Anandamide is produced in spleen (41), but little is known about the production of this agonist along with other putative CBR agonists such as 2-arachidonyl glycerol (54) and palmitoylethanolamide (55) in immune tissues of various origins and under varying conditions of stress. It is known that immune cells contain high levels of the fatty acid precursors for these agonists, and, in addition, metabolites of this group of chemicals (eg, arachidonic acid) have been shown to be powerful regulators of immune cell activity. Expectations are high, therefore, that CBR agonists are generated during the course of immune activity and play a role in immune regulation. In the future, some of these questions may be answered with the aid of the newly described CBR knockout mice. Although neither knockout is grossly immunodeficient (56-58), further indepth studies may reveal the immune mechanisms regulated by CBRs.

\section{Cannabinoid use in AIDS and multiple sclerosis}

Several chronic diseases have been targeted for trial treatment with cannabinoids. Among these are AIDS wasting and movement disorders, such as multiple sclerosis (1). Because it is recognized that smoked marijuana is a crude delivery system for THC, which also delivers harmful substances, a key issue in the use of cannabinoids in these diseases is the development of suitable THC formulations, and delivery systems that are safer and more effective than marijuana smoking. Devices such as inhalers and cutaneous patches are already under development; however, drug formulations containing THC and other active substances from marijuana have yet to be produced.

\section{Antitumour effects of cannabimimetic agents}

Cannabimimetics have been shown to alter the course of hematopoietic and tumour cell growth. For example, anandamide was shown to enhance significantly the proliferative effect of IL-3 on the myeloid cell line 32Dcl3 (59) by means of a CB2-mediated mechanism. On the other hand, anandamide suppressed the proliferation of breast and prostate cancer cell lines through mechanisms involving the suppression of prolactin and nerve growth factor receptors (60). This suppressive effect extended to several cannabinoid agonists and appeared to involve the CB1 receptor. These studies raise a key question concerning the potential effect of cannabimimetics on tumour growth. Are cancer patients at greater risk if they decide to use marijuana to control nausea? On the other hand, may these drugs have a real antitumour potential under the right conditions? Regarding the latter question, a recent report suggests that these compounds can suppress tumour growth in mice and rats (61). C6 glioma cell tumours were established in the animals, and they were treated with THC or other cannabimimetics for up to seven days. This treatment extended survival and led to shrinkage of tumour size (61). It was also shown that the mechanism of action of the drug involved the induction of apoptosis in the tumour cells. This is one of several reports that have shown that cannabinoids induce apoptosis $(62,63)$, and it is possible that programmed cell death may be a key mechanism of action of cannabimimetic agents in a variety of tissues, including tumours.

\section{Anti-inflammatory effects of cannabinoids}

Marijuana and cannabinoids are recognized analgesics, and recently, nonpsychoactive derivatives have been shown to have anti-inflammatory effects. The dimethylheptyl derivative of THC-11-oic acid, when given orally to mice, suppressed both acute and chronic inflammatory changes (64). Furthermore, this compound was shown to be an effective analgesic and anti-inflammatory agent, in addition to being tolerated well by the host following oral administration (65). Another nonpsychoactive cannabinoid, HU-211, has been shown, in several studies, to suppress inflammation that is caused through the mobilization of cytokines such as TNF- $\alpha$ 
$(66,67)$. From these studies, a key issue emerges involving linkage between the effects of cannabinoids on cytokines and the effects of these agents on inflammation. It is possible that suppression of cytokine production or function is at the core of the drug effects on inflammation. Cannabimimetic agents have broad effects on cytokine biology (5), suggesting that under various conditions, these drugs may have either proinflammatory or anti-inflammatory effects. Further studies are needed to resolve these possibilities.

\section{CONCLUSIONS}

A variety of factors point to increased use of marijuana and cannabinoids in the United States and Canada over the next few years. Although much has been learned concerning the chemistry and biology of these agents, much more needs to be discovered in all areas of cannabinoid biology, including effects on immune function. The immune system is extremely complex, consisting of a variety of organs, cells, tissues and soluble factors working together to produce a

\section{REFERENCES}

1. Joy JE, Watson SJ, Benson JA. Marijuana and Medicine: Assessing the Science Base. Washington: National Academy Press, 1999.

2. Kaminski N. Regulation of the cAMP cascade, gene expression and immune function by cannabinoid receptors. J Neuroimmunol 1998;83:124-32.

3. Cabral G, Dove Pettit D. Drugs and immunity: cannabinoids and their role in decreased resistance to infectious diseases. J Neuroimmunol 1998;83:116-23.

4. Klein T, Newton C, Friedman H. Cannabinoid receptors and immunity. Immunol Today 1998;19:373-81.

5. Klein TW, Lane B, Newton CA, Friedman H. The cannabinoid system and cytokine network. Proc Soc Exp Biol Med 2000;225:1-8.

6. Klein TW, Newton C, Snella E, Friedman H. Marijuana, the cannabinoid system and immunomodulation. In: Ader R, Felten D, Cohn N, eds. Psychoneuroimmunology, 3rd edn. New York: Academic Press, 2000.

7. Parolaro D. Presence and functional regulation of cannabinoid receptors in immune cells. Life Sci 1999;65:637-44.

8. Nahas GG, Suciu-Foca N, Armand J-P, Morishima A. Inhibition of cellular mediated immunity in marihuana smokers. Science 1974;183:419-20.

9. Lau RJ, Tubergen DG, Barr M, Domino EF. Phytohemagglutinininduced lymphocyte transformation in humans receiving $\Delta^{9}$-tetrahydrocannabinol. Science 1976;192:805-7.

10. Baldwin GC, Tashkin DP, Buckley DM, Park AN, Dubinett SM, Roth MD. Marijuana and cocaine impair alveolar macrophage function and cytokine production. Am J Respir Crit Care Med 1997; $156: 1606-13$.

11. Daul CB, Heath RG. The effect of chronic marihuana usage on the immunological status of rhesus monkeys. Life Sci 1975;17:875-82.

12. Zimmerman S, Zimmerman AM, Cameron IL, Laurence HL. $\Delta$ 1-tetrahydrocannabinol, cannabidiol and cannabinol effects on the immune response of mice. Pharmacology 1977;15:10-23.

13. Titishov N, Mechoulam R, Zimmerman AM. Stereospecific effects of (-)- and (+)-7-hydroxy-delta-6-tetrahydrocannabinol-dimethylheptyl on the immune system of mice. Pharmacology 1989;39:337-49.

14. Klein TW, Newton C, Friedman H. Inhibition of natural killer cell function by marijuana components. J Toxicol Environ Health 1987;20:321-32.

15. Burnette-Curley D, Marciano-Cabral F, Fischer-Stenger K, Cabral GA. Delta-9-tetrahydrocannabinol inhibits cell contactdependent cytotoxicity of Bacillus Calmette-Guerin-activated macrophages. Int J Immunopharmacol 1993;15:371-82.

16. Klein TW, Newton CA, Nakachi H, Friedman H. $\Delta^{9}$-tetrahydrocannabinol treatment suppresses immunity and early IFN- $\gamma$, IL-12, and IL-12 receptor $\beta 2$ responses to Legionella pneumophila infection. J Immunol 2000;164:6461-6.

17. Zhu LX, Sharma S, Stolina M, et al. $\Delta-9$-tetrahydrocannabinol inhibits plethora of effector functions. This complexity provides many avenues for cannabinoids to alter immune function, and over the past decade or so, many of these avenues have been examined. From a variety of experimental paradigms, cannabinoids have been shown repeatedly to modulate immune function. However, from these studies, it cannot be concluded that marijuana smoking causes severe immunodeficiency in humans. What can be concluded is that these drugs have the potential to modulate immune function through both receptor- and non-receptor-mediated mechanisms. Clearly, additional studies are needed to determine the precise structure and function of the putative immunocannabinoid system; the potential therapeutic usefulness of these drugs in chronic diseases such as AIDS and multiple sclerosis; the effects of these agents on tumour growth and induction of apoptosis; and the potential anti-inflammatory and proinflammatory properties of cannabimimetic compounds. It is likely that the cannabinoid system, along with other neuroimmune systems, has a subtle but significant role

antitumor immunity by a $\mathrm{CB} 2$ receptor-mediated,

cytokine-dependent pathway. J Immunol 2000;165:373-80.

18. Nahas GG, Morishima A, Desoize B. Effects of cannabinoids on macromolecular synthesis and replication of cultured lymphocytes. Fed Proc 1977;36:1748-52.

19. Specter S, Klein TW, Newton C, Mondragon M, Widen R, Friedman H. Marijuana effects on immunity: suppression of human natural killer cell activity by delta-9-tetrahydrocannabinol. Int J Immunopharmacol 1986;8:741-5.

20. Derocq J, Segui M, Marchand J, LeFur G, Casellas P. Cannabinoids enhance human B-cell growth at low nanomolar concentrations. FEBS Lett 1995;369:177-82.

21. Zheng Z-M, Specter S, Friedman H. Inhibition by delta-9-tetrahydrocannabinol of tumor necrosis factor alpha production by mouse and human macrophages. Int J Immunopharmacol 1992;14:1445-52.

22. Stefano GB, Liu Y, Goligorsky MS. Cannabinoid receptors are coupled to nitric oxide release in invertebrate immunocytes, microglia, and human monocytes. J Biol Chem 1996;271:19238-42.

23. Klein TW, Newton CA, Widen R, Friedman H. The effect of delta-9-tetrahydrocannabinol and 11-hydroxy-delta-9tetrahydrocannabinol on T lymphocyte and B lymphocyte mitogen responses. J Immunopharmacol 1985;7:451-66.

24. Lee M, Yang KH, Kaminski NE. Effects of putative cannabinoid receptor ligands, anandamide and 2-arachidonyl-glycerol, on immune function in B6C3F1 mouse splenocytes. J Pharmacol Exp Ther 1995;275:529-36.

25. Klein TW, Kawakami Y, Newton C, Friedman H. Marijuana components suppress induction and cytolytic function of murine cytotoxic T cells in vitro and in vivo. J Toxicol Environ Health 1991;32:465-77.

26. Patel V, Borysenko M, Kumar MSA, Millard WJ. Effects of acute and subchronic $\Delta 9$-tetrahydrocannabinol administration on the plasma catecholamine, B-endorphin, and corticosterone levels and splenic natural killer cell activity in rats. Proc Soc Exp Biol Med 1985;180:400-4.

27. Baczynsky WOT, Zimmerman AM. Effects of $\Delta^{9}$-tetrahydrocannabinol, cannabinol and cannabidiol on the immune system in mice: II. in vitro investigation using cultured mouse splenocytes. Pharmacology 1983;26:12-9.

28. Klein TW, Newton C, Zhu W, Daaka Y, Friedman H. Minireview: $\Delta^{9}$-tetrahydrocannabinol, cytokines and immunity to Legionella pneumophila. Proc Soc Exp Biol Med 1995;209:205-12.

29. Ouyang Y, Hwang SG, Han SH, Kaminski NE. Suppression of interleukin-2 by the putative endogenous cannabinoid 2-arachidonylglycerol is mediated through down-regulation of the nuclear factor of activated T cells. Mol Pharmacol 1998;53:676-83.

30. Daaka Y, Zhu W, Friedman H, Klein TW. Induction of IL-2 receptor a 
gene by $\Delta^{9}$-tetrahydrocannabinol is mediated by nuclear factor $\kappa \mathrm{B}$ and CB1 cannabinoid receptor. DNA Cell Biol 1997;16:301-9.

31. McCoy KL, Matveyeva M, Carlisle SJ, Cabral GA. Cannabinoid inhibition of the processing of intact lysozyme by macrophages: evidence for CB2 receptor participation. J Pharmacol Exp Ther 1999;289:1620-5.

32. Ader R, Felten DL, Cohen N, eds. Psychoneuroimmunology, 3rd edn. New York: Academic Press, 2001:1583.

33. Howlett AC, Johnson MR, Melvin LS, Milne GM. Nonclassical cannabinoid analgetics inhibit adenylate cyclase: Development of a cannabinoid receptor model. Mol Pharmacol 1988;33:297-302.

34. Matsuda LA, Lolait SJ, Brownstein MJ, Young AC, Bonner TI. Structure of cannabinoid receptor and functional expression of the cloned cDNA. Nature 1990;346:561-4.

35. Munro S, Thomas KL, Abu-Shaar M. Molecular characterization of a peripheral receptor for cannabinoids. Nature 1993;365:61-5.

36. Ji TH, Grossmann M, Ji I. G protein-coupled receptors I. Diversity of receptor-ligand interactions. J Biol Chem 1998;273:17299-302.

37. Bonhaus DW, Chang LK, Kwan J, Martin GR. Dual activation and inhibition of adenylyl cyclase by cannabinoid receptor agonists: evidence for agonist-specific trafficking of intracellular responses. J Pharmacol Exp Ther 1998;287:884-8.

38. Sengupta TK, Schmitt EM, Ivashkiv LB. Inhibition of cytokines and JAK-STAT activation by distinct signaling pathways. Proc Natl Acad Sci USA 1996;93:9499-504.

39. Felder C, Glass M. Cannabinoid receptors and their endogenous agonists. Annu Rev Pharmacol Toxicol 1998;38:179-200.

40. Martin BR, Mechoulam R, Razdan RK. Discovery and characterization of endogenous cannabinoids. Life Sci 1999;65:573-95.

41. Felder CC, Nielsen A, Briley EM, et al. Isolation and measurement of the endogenous cannabinoid receptor agonist, anandamide, in brain and peripheral tissues of human and rat. FEBS Lett 1996;393:231-5.

42. Gerard CM, Mollereau C, Vassart G, Parmentier M. Molecular cloning of a human cannabinoid receptor which is also expressed in testis. Biochem J 1991;279:129-34.

43. Kaminski NE, Abood ME, Kessler FK, Martin BR, Schatz AR. Identification of a functionally relevant cannabinoid receptor on mouse spleen cells that is involved in cannabinoid-mediated immune modulation. Mol Pharmacol 1992;42:736-42.

44. Bouaboula M, Rinaldi M, Carayon P, et al. Cannabinoid-receptor expression in human leukocytes. Eur J Biochem 1993;214:173-80.

45. Galieque S, Mary S, Marchand J, et al. Expression of central and peripheral cannabinoid receptors in human immune tissues and leukocyte subpopulations. Eur J Biochem 1995;232:54-61.

46. Noe SN, Newton C, Widen R, Friedman H, Klein TW. Anti-CD40, anti-CD3, and IL-2 stimulation induce contrasting changes in CB1 mRNA expression in mouse splenocytes. J Neuroimmunol 2000;110:161-7.

47. Wenger T, Fernandez-Ruiz JJ, Ramos JA. Immunocytochemical demonstration of CB1 cannabinoid receptors in the anterior lobe of the pituitary gland. J Neuroendocrinol 1999;11:873-8.

48. Heinemann A, Shahbazian A, Holzer P. Cannabinoid inhibition of guinea-pig intestinal peristalsis via inhibition of excitatory and activation of inhibitory neural pathways. Neuropharmacology 1999;38:1289-97.

49. Daaka Y, Friedman H, Klein TW. Cannabinoid receptor proteins are increased in Jurkat, human T-cell line after mitogen activation. J Pharmacol Exp Ther 1996;276:776-83.

50. Carayon P, Marchand J, Dussossoy D, et al. Modulation and functional involvement of $\mathrm{CB} 2$ preipheral cannabinoid receptors during B-cell differentiation. Blood 1998;92:3605-15.

51. Condie R, Herring A, Koh WS, Lee M, Kaminski NE. Cannabinoid induction of adenylate cyclase-mediated signal transduction and interleukin 2 (IL-2) expression in the murine T-cell line, EL4 IL-2. J Biol Chem 1996;271:13175-83.

52. Bouaboula M, Poinot-Chazel C, Bourrie B, et al. Activation of mitogen-activated protein kinases by stimulation of the central cannabinoid receptor CB1. Biochem J 1995;312:637-41.

53. Bouaboula M, Bourrie B, Rinaldi-Carmona M, Shire D, LeFur G, Casellas P. Stimulation of cannabinoid receptor CB1 induces krox-24 expression in human astrocytoma cells. J Biol Chem 1995;270:13973-80.

54. Mechoulam R, Ben-Shabat S, Hanus L, et al. Identification of an endogenous 2-monoglyceride, present in canine gut, that binds to cannabinoid receptors. Biochem Pharmacol 1995;50:83-90.

55. Bisogno T, Maurelli S, Melck D, De Petrocellis L, Di Marzo V. Biosynthesis, uptake, and degradation of anandamide and palmitoylethanolamide in leukocytes. J Biol Chem 1997;272:3315-23.

56. Ledent C, Valverde O, Cossu G, et al. Unresponsiveness to cannabinoids and reduced additive effects of opiates in CB1 receptor knockout mice. Science 1999;283:401-4.

57. Zimmer A, Zimmer AM, Hohmann WG, Herkenham M, Bonner TI. Increased mortality, hypoactivity, and hypoalgesia in cannabinoid CB1 receptor knockout mice. Proc Natl Acad Sci USA 1999;96:5780-5.

58. Buckley NE, McCoy KL, Mezey E, et al. Immunomodulation by cannabinoids is absent in mice deficient for the cannabinoid CB2 receptor. Eur J Pharmacol 2000;396:141-9.

59. Valk P, Verbakel S, Vankan Y, et al. Anandamide, a natural ligand for the peripheral cannabinoid receptor is a novel synergistic growth factor for hematopoietic cells. Blood 1997;90:1448-57.

60. Melck D, De Petrocellis L, Orlando P, et al. Suppression of nerve growth factor Trk receptors and prolactin receptors by endocannabinoids leads to inhibition of human breast and prostate cancer cell proliferation. Endocrinology 2000;141:118-26.

61. Galve-Roperh I, Sanchez C, Cortes ML, del Pulgar TG, Izquierdo M, Guzman M. Anti-tumoral action of cannabinoids: involvement of sustained ceramide accumulation and extracellular signal-regulated kinase activation. Nat Med 2000;6:313-9.

62. Schwarz H, Blanco FJ, Lotz M. Anandamide, an endogenous cannabinoid receptor agonist inhibits lymphocyte proliferation and induces apoptosis. J Neuroimmunol 1994;55:107-15.

63. Zhu W, Friedman H, Klein TW. D9-tetrahydrocannabinol induces apoptosis in macrophages and lymphocytes: involvement of Bcl-2 and caspase-1. J Pharmacol Exp Ther 1998;286:1103-9.

64. Zurier RB, Rossetti RG, Lane JH, Goldberg JM, Hunter SA, Burstein SH. Dimethylheptyl-THC-11 oic acid. A nonpsychoactive antiinflammatory agent with a cannabinoid template structure. Arthritis Rheum 1998;41:163-70.

65. Dajani EZ, Larsen KR, Taylor J, et al. 1',1'-Dimethylheptyl-delta-8tetrahydrocannabinol-11-oic acid: a novel, orally effective cannabinoid with analgesic and anti-inflammatory properties. J Pharmacol Exp Ther 1999;291:31-8.

66. Bass R, Engelhard D, Trembovler V, Shohami E. A novel nonpsychotropic cannabinoid, HU-211, in the treatment of experimental pneumococcal meningitis. J Infect Dis 1996;173:735-8.

67. Shohami E, Gallily R, Mechoulam R, Bass R, Ben-Hur T. Cytokine production in the brain following closed head injury: dexanabinol (HU-211) is a novel TNF-alpha inhibitor and an effective neuroprotectant. J Neuroimmunol 1997;72:169-77. 


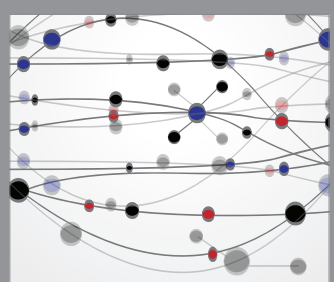

The Scientific World Journal
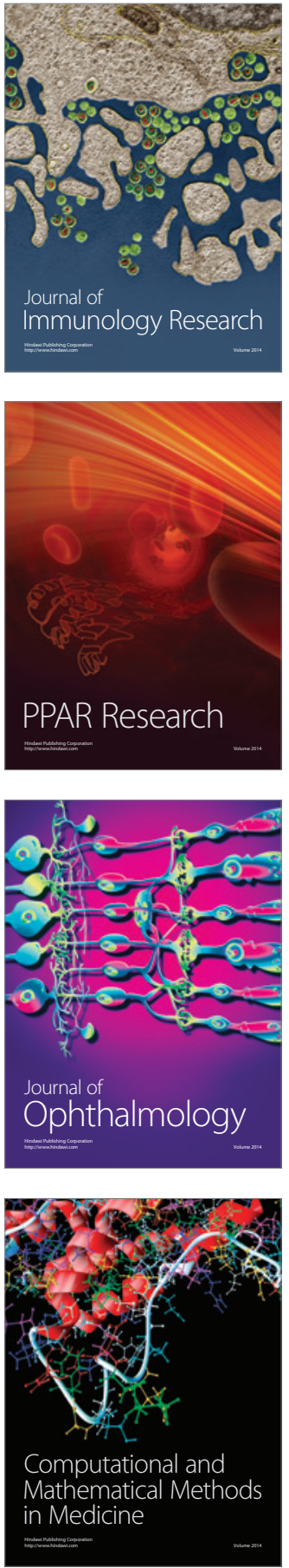

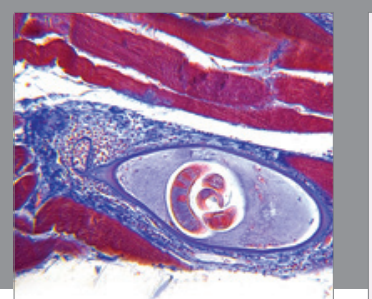

Gastroenterology Research and Practice

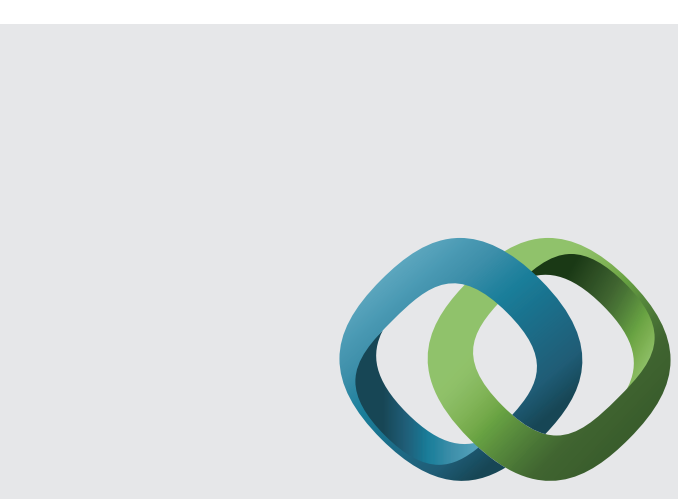

\section{Hindawi}

Submit your manuscripts at

http://www.hindawi.com
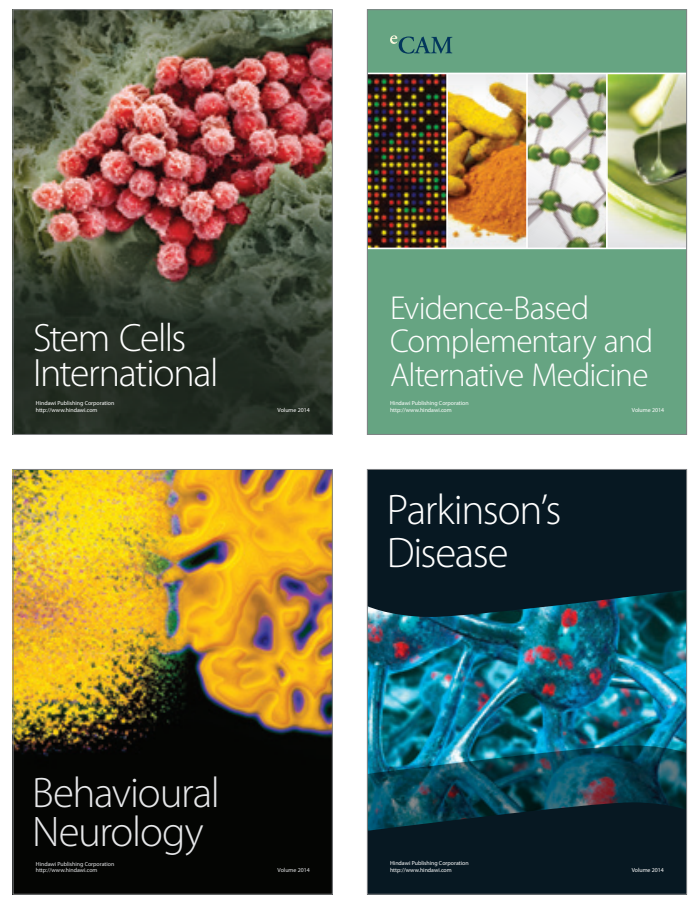
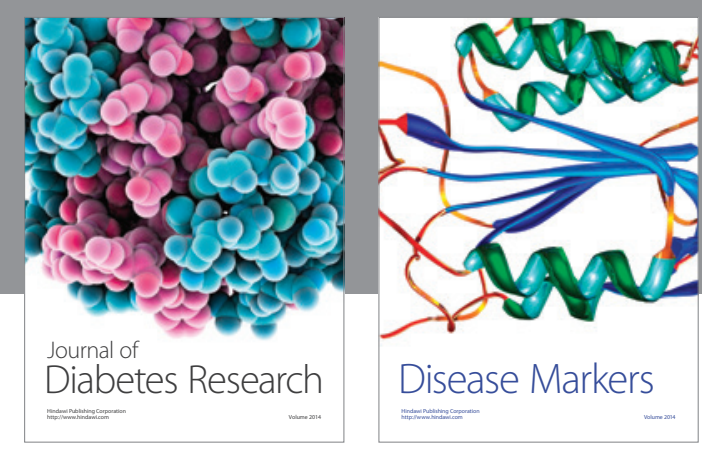

Disease Markers
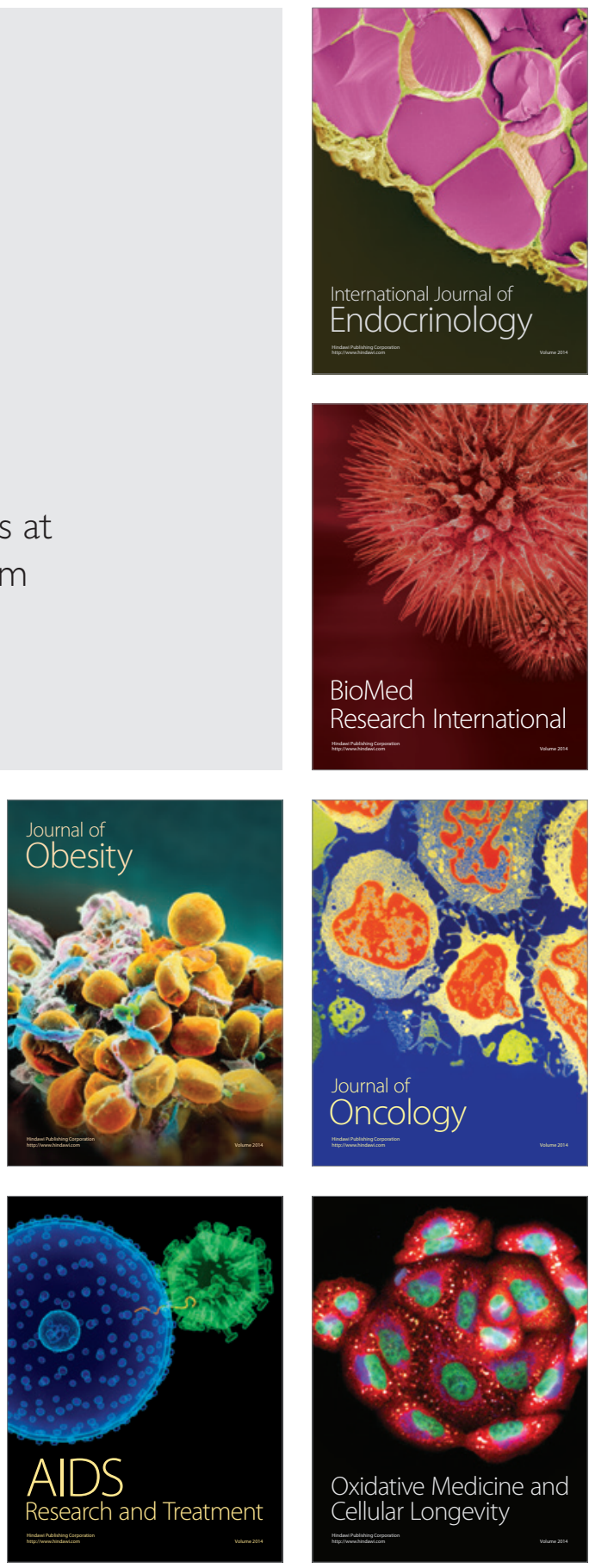